\title{
PENDIDIKAN MULTIKULTURAL DALAM PEMBELAJARAN SEJARAH: UPAYA MENINGKATKAN NASIONALISME
}

\author{
Oleh: \\ Risma Ariyani \\ NIM. 1810111220028 \\ Email: 1810111220028@mhs.ulm.ac.id \\ Program Studi Pendidikan Sejarah Fakultas Keguruan Dan Ilmu Pendidkan \\ Universitas Lambung Mangkurat \\ Banjarmasin
}

\begin{abstract}
Abstrak
Negara Indonesia tumbuh dengan keragaman, baik itu bahasa, agama, suku, ras, adat, dan budaya. Keberagaman ini tidak terlepas dari proses keberlanjutan dalam sejarah. Pembelajaran berbasis nilai-nilai kebhinekaan sangat penting di tengah pluralisme budaya Indonesia dan pengaruh globalisasi. Penanaman nilai dan makna multikultural melalui pembelajaran sejarah salah satu langkah yang tepat dan mendasar dalam meningkatkan rasa kebangsaan.

Kata kunci: Pembelajaran Sejarah, Multikultural, Nasionalisme, Pluralisme Budaya

\section{Pendahuluan}

Ciri khas Indonesia sebagai bangsa yang kaya akan keberagaman atas hasil dari perjalanan sejarah terdahulunya yang menjadikan identitas nasional Indonesia sendiri. Menurut Erwin (dalam Anis, Mardiani, dan Fathurrahman: 2021) menjelaskan bahwa identitas nasional yang terdiri dari istilah identitas yang berasal dari istilah identity dan nasional yang berangkat dari istilah nation, yang mana identitas (identity) dapat diterjemahkan sebagai karakter, ciri, tanda, jati diri ataupun sifat khas, sementara nasional (nation) yang artinya bangsa; maka
\end{abstract}


identitas nasional itu merupakan sifat khas yang melekat pada suatu bangsa atau yang lebih dikenal sebagai kepribadian/karakter suatu bangsa. Hidup di tengah keragaman budaya, bahasa, suku, agama dan ras menjadi identitas bangsa Indonesia. Indonesia terlahir sebagai negara multikultural. Keragaman ini merupakan salah satu pengaruh dari peistiwa-peristiwa sejarah masa lampau.

Ditengah pesatnya arus kemajuan teknologi informasi, pola pikir masyarakat jauh lebih terbuka pada hal-hal baru. Pembaruan dapat diterima dengan mudah tanpa melihat akibat positif dan negatifnya. Kemajuan tidak terbatas ini, dapat memengaruhi keutuhan jati diri dalam masyarakat. Maka dari itu, diperlukan pembelajaran yang dapat menanamkan nilai nilai kebangsaan terlebih lagi Indonesia yang hidup dalam keberagaman. Peran pembelajaran sejarah sangat tepat untuk meningkatkan sikap nasionalisme berdasarkan sudut pandang peristiwa sejarah. Menurut Pi'I (dalam Anis, Mardiani, dan Fathurrahman: 2021) bahwa pembelajaran sejarah dinilai sangat strategis dan efektif dalam menanamkan nilai-nilai kebhinekaan kepada siswa. Pembelajaran sejarah merupakan suatu proses transfer nilai berdasarkan peristiwa-peristiwa terdahulu yang masih relevan di masa sekarang dan menetukan masa depan (keberlanjutan). Hal ini sejalan tujuan pembelajaran sejarah menurut Anis (2015), bahwa tujuan sejarah untuk mengembangkan pemahaman diri sendiri, sehingga bangsa kita tahu apa arti menjadi bangsa Indonesia, tanpa sejarah juga generasi muda tidak tahu bagaimana para pendahulu secara gigih memperjuangkan kemerdekaan, tanpa sejarah para politikus generasi baru tidak akan pernah tahu mengenai struktur negara yang Pancasilais yang menjadi ideologi negara.

Hasil dari proses interaksi antarperistiwa-peristiwa sejarah yang dalam perkembangannya dapat membentuk sikap dan identitas bangsa. Seperti yang dijelaskan oleh Isnarmi (2014), bahwa sejarah perjuangan kemerdekaan bangsa menuju terbentuknya Negara Kesatuan Republik Indonesia, merupakan rangkaian bukti yang menunjukkan bahwa nilai-nilai multikultural telah menjadi bagian dalam kehidupan masyarakat sekaligus kehidupan politik bangsa Indonesia. Nilainilai multikultural yang hadir dan berkembang pada masyarakat Indonesia seiring 
perubahan pola pikir dan pengaruh aspek religi menandakan kemajemukan identitas bangsa.

Pentingnya menambahkan unsur-unsur pendidikan multikultural dalam muatan mata pelajaran ilmu-ilmu sosial sebagai upaya penanaman rasa nasionalisme. Pada pembelajaran sejarah, nilai-nilai multikultural dapat dikaitkan dengan peristiwa-peristiwa masa lalu yang syarat akan makna. Dalam artian pendidikan multikultural dilihat dari sudut pandang sejarah. Dengan demikian diharapkan rasa cinta tanah air akan tetap tumbuh di tengah pesatnya arus globalisasi.

\section{Pembahasan}

\section{A. Definisi Pendidikan Multikultural}

Pada dasarnya pendidikan multikultural merupakan proses pembelajaran dengan konsep perbedaan, keberagaman dan kesetaraan. Menurut Sleeter and Grant (dalam Suryana dan Rusdiana: 2015) menjelaskan pembelajaran multikultural adalah kebijakan dalam praktik pendidikan dalam mengakui, menerima, dan menegaskan perbedaan dan persamaan manusia yang dikaitkan dengan gender, ras, dan kelas.

Liliweri (dalam Suryana dan Rusdiana: 2015) mendefirisikan pembelajaran multikultural (multicultural education) merupakan strategi pendidikan yang memanfaatkan keberagaman latar belakang kebudayaan dari para peserta didik sebagai salah satu kekuatan untuk membentuk sikap multikultural. Strategi ini sangat bermanfaat, sekurang-kurangnya bagi sekolah sebagai lembaga pendidikan dapat membentuk pemahaman bersama atas konsep kebudayaan, perbedaan budaya, keseimbangan, dan demokrasi dalam arti yang luas.

Rochiati Wiriatmadja (dalam Isnarmi: 2014) "tujuan pendidikan multikultur adalah untuk mempersiapkan anak didik dengan sejumlah 
pengetahuan, sikap dan keterampilan yang diperlukan dalam lingkungan budaya etnik mereka, budaya nasional, dan antar budaya etnik lainnya".

Dengan demikian, pendidikan multikultural ialah salah satu strategi dalam pendidikan yang mengedepankan asas-asas perbedaan ras, suku, agama dan budaya yang ditanamkan kepada siswa guna menumbuhkan sikap multikultural, sikap toleransi dalam perbedaan dan membentuk jati diri bangsa.

\section{B. Pendidikan Multikultural dalam Pembelajaran Sejarah sebagai Upaya}

\section{Meningkatkan Rasa Kebangsaan}

Definisi sejarah menurut Sutherland (dalam Anis: 2016), bahwa sejarah mengandung dua arti, pertama adalah narasi kronologi yang dieksekusi untuk disusun, kedua meliputi elemen-elemen masa lalu yang dipilih dan diberi peran untuk menjelaskan dunia kekinian. Dalam konteks kekinian, sejarah dapat diartikan sebagai proses penyerapan makna dan nilai berdasarkan peristiwa sejarah yang masih relevan untuk masa sekarang. Dalam hal yang lebih spesifik, sejarah sebagai penguat jati diri berdasarkan proses tranfer nilai.

Terkhusus pada sejarah peristiwa penting berbau kebangsaan, proses pemindahan nilai nilai itu akan lebih mudah tersalurkan dikarenakan adanya kesamaan nasib, upaya perjuangan dan sebagainya. Nilai kebanggaan itu lahir di tengah perbedaan-perbedaan yang terhimpun menjadi satu kesatuan. Anis (2016), menjelaskan pengalaman sejarah yang membangun keberagaman primordialisme menjadi sebuah kesatuan politik yang kita sebut dengan negara nasional. Sejarah nasional yang hanya dapat memberikan informasi tentang terbentuknya sebuah identitas baru, yaitu identitas nasional.

Pembelajaran sejarah berbasis multikultural sangat efektif diterapkan pada pendidikan di Indonesia, mengingat kemajemukan budaya Indonesia yang tidak terlepas dari proses interaksi peristiwa sejarah. Secara historis, ideologi keragaman itu dipertautkan menjadi sebuah struktur ekonomis dan politis bersama. Sejarah terbentuknya NKRI tahun 1945 membuktikan bagaimana 
keragaman suku, agama, dan keturunan dipersatukan dalam satu cita-cita bernegara Republik Indonesia (Risalah Sidang BPUPKI/PPKI 1945 oleh Setneg RI 1995, dalam Isnarmi: 2014).

Pendidikan berbasis multikultural ini perlu diimplementasikan dikarenakan besarnya peluang yang dapat dimanfaatkan. Proses tranfer nilai akan lebih efisiens jika disesuaikan dengan kondisi lingkungan masyarakat. Menurut Isnarmi (2014) dari sudut pandang pendidikan, kondisi masyarakat Indonesia yang beragam secara etnik masih merupakan potensi yang perlu dikembangkan melalui program pendidikan atau mata pelajaran yang khusus dan terarah kepada pengembangan pengetahuan, sikap, dan keterampilan multikultural di kalangan siswa.

Untuk mewujudkan potensi tersebut, diperlukan pembaruan antara pendidikan multikultural ke dalam mata pelajaran ilmu-ilmu sosial seperti, sejarah, IPS, dan PKN. Cara ini cukup efisien dan tepat untuk diterapkan tanpa harus mengubah tatanan atau sistem pendidikannya. Tanpa menggangu isi dan tuntutan kurikulum mata pelajaran terkait, konsep kunci, prinsip dan generalisasi dari disiplin ilmu yang berkaitan dengan pendidikan multikultural dapat dikembangkan oleh guru. Selain itu proses pengitegrasian ini juga akan merangsang keterampilan berfikir kritis dan kemampuan partisipatif sebagai upaya pembentukan sikap-sikap multikultural (Isnarmi: 2014).

\section{Kesimpulan}

Konsep keberagaman dalam masyarakat Indonesia tidak terlepas dari imbas interaksi masa lalu peristiwa-peristiwa syarat makna. Sikap rela berkorban di tengah kemajemukan budaya bangsa Indonesia pada masa perjuangan kemerdekaan yang akhirnya membentuk identitas nasional. Pada era revolusi industri 4.0 teknologi merupakan kunci utama dalam proses perkembangan ilmu pengetahuan. Perkembangan yang sangat terbuka membuat sulitnya melakukan pengontrolan terhadap masuknya informasi sehingga pola pikir menjadi lebih luas 
dan mungkin saja diperburuk dengan tidak adanya batasan-batasan nilai dan norma. Hal ini menyababkan perubahan pola pikir dan memudarnya jati diri bangsa. Dalam upaya meningkatkan dan mempertahankan rasa kebangsaan gerusan arus globalisasi, pentingnya penanaman nilai nilai multikultural pada pembelajaran sejarah berdasarkan proses penafsiran makna pada peristiwa masa lampau (sudut pandang historis).

\section{Daftar Pustaka}

Anis, M. Z. A. (2015). Sejarah Bukan Warisan Melainkan Pembelajaran.

Anis, M. Z. A. (2016). Sejarah, Kesadaran Sejarah dan Pupusnya Identitas Nasional.

Isnarmi, I. (2014). Pendidikan Multikultural Transformatif: Integritas Moral, Dialogis dan Adil.

Mardiani, M. Z. A. A. F. (2021). MEMPERKUAT IDENTITAS NASIONAL MELALUI MODEL PEMBELAJARAN BERPIKIR HISTORIS (MPBH): ANTARA NYATA ATAU SEBUAH ASA?. In PROSIDING SEMINAR NASIONAL LINGKUNGAN LAHAN BASAH (Vol. 6, No. 3).

Suryana, Y., \& Rusdiana, A. (2015). Pendidikan Multikultural Suatu Upaya Penguatan Jati Diri Bangsa: Konsep, Prinsip, dan Implementasi. Pustaka Setia. 